\title{
The Miocene Climatic Optimum: evidence from ectothermic vertebrates of Central Europe
}

\author{
Madelaine Böhme* \\ Universitätsinstitut und Staatssammlung für Paläontologie und historische Geologie München, Richard-Wagner-Str. 10, \\ D-80333 Munich, Germany
}

Received 16 November 2001; accepted 18 March 2003

\begin{abstract}
Data sets of Central European temporal distributions of thermophilic ectothermic vertebrates (Channidae, Varanidae, Chamaeleonidae, Cordylidae, Tomistomidae, Alligatoridae, giant turtles) and of North Alpine Foreland Basin (NAFB) distributions of ectothermic vertebrates adapted to dryer habitats (Albanerpeton inexpectatum, Salamandra sansaniensis, Bufo cf. viridis, Chamaeleo caroliquarti, Gekkonidae, Varanus hofmanni, Bransateryx sp.) are analysed. Two main migration events of thermophilic ectotherms at $20 \mathrm{Ma}$ and $18 \mathrm{Ma}$ in the Lower Miocene are discerned. They indicate the beginning of the Miocene Climatic Optimum in Central Europe $\left(42-45^{\circ} \mathrm{N}\right.$ palaeolatitude) with a lower limit of the mean annual temperature (MAT) of $17.4^{\circ} \mathrm{C}$ derived from the minimal MAT of their extant relatives. Furthermore, additional palaeobotanical data and records of bauxite point to a MAT of $22^{\circ} \mathrm{C}$. This warm and humid optimum peaked at 18-16.5 Ma (Ottnangian, Karpatian), and is confirmed by the coexistence of all investigated thermophilic taxa. The following period (Early Badenian) is characterised by probably unchanged temperatures but a seasonality in precipitation with dry periods up to six months. Two major seasonal phases between 16.3 and $\sim 15.7 \mathrm{Ma}$ (earliest Early Badenian) and between 14.7 and $\sim 14.5 \mathrm{Ma}$ (Early/Middle Badenian transition) are indicated by an immigration of dry adapted taxa from the surrounding karst plateau to the NAFB. It is presumed that the tectonical reorganisation of the Central Paratethys realm had considerable influence on this regional humidity pattern. The warm period ended abruptly between 14.0 and 13.5 Ma (Middle/Late Badenian transition) with major regional extinction events of most of the thermophilic groups in Central Europe and a drop of the MAT of probably more than $7^{\circ} \mathrm{C}$ to temperatures around $14.8-15.7^{\circ} \mathrm{C}$. This drop can be attributed predominantly to a decrease of more than $11^{\circ} \mathrm{C}$ of the minimum cold months temperature. This temperature decrease marked the beginning of a climatic zonation of the European continent and is also evidenced by a progressively southward disappearance of the crocodile Diplocynodon from $38-45^{\circ} \mathrm{N}$ palaeolatitude to $30-37^{\circ} \mathrm{N}$ during the Middle and earliest Late Miocene. The results correlate well with palaeobotanical data from the mid-latitudes of Europe and North America, and the deep-sea temperature curve generated from oxygen isotope ratios.
\end{abstract}

(C) 2003 Elsevier Science B.V. All rights reserved.

Keywords: climate; Miocene; ectothermic vertebrates; amphibians; reptiles

\footnotetext{
* Fax: +49-89-21806601.

E-mail address: m.boehme@1rz.uni-muenchen.de
} (M. Böhme).

\section{Introduction}

The complex history of global climate evolution 
during the Cenozoic is being reconstructed in more and more detail, which is especially due to the high-resolution deep-sea $\delta^{18} \mathrm{O}$ isotope records, and the establishment of an 'astronomically calibrated' geological time scale (Zachos et al., 2001). One of the most remarkable episodes is the MidMiocene Climatic Optimum, between 17 and 15 Ma. According to Flower and Kennett (1994), this climax of Neogene warmth was followed by short-term variation in the East Antarctic Ice Sheet volume, sea level, deep ocean circulation and in global climates (between $\sim 16.0$ and 14.8 Ma). A major and permanent cooling step occurred between 14.8 and $14.1 \mathrm{Ma}$, associated with increased production of cold Antarctic deep waters and a major growth of the East Antarctic ice sheet. As a result, the meridional temperature gradient increased, the boundaries between climatic zones strengthened and the aridification of the mid-latitudes increased (Flower and Kennett, 1994).

The climatic zonation of the world is reflected by the zonal distribution of vegetation types. But, in contrast to plants, animals have looser affinities to distinct climatic zones (Ostrom, 1970; Walter and Breckle, 1983). Many ectothermic vertebrates are physiologically adapted (e.g. due to dormancy) to seasonal climatic change. Thus, many reptiles of the tropics occur also in subtropical climates (Haller-Probst, 1997). Therefore, tropical climate (daily thermal gradient $>$ annual thermal gradient) cannot be recognised with certainty based on ectothermic vertebrates only, because in most cases only the lower limit of temperature is practically useful. Other proxies, such as palaeobotanical or geochemical data can help to improve the analysis.

Many recent studies of climate/evolution paradigms have focused on mammals. E.g. Alroy et al. (2000) claim that the global climate change had only unpredictable effects on the Cenozoic mammalian evolution in western North America. In contrast to mammals, however, fishes, amphibians and reptiles are ectothermic and their distribution is highly dependent on temperature (Markwick, 1998). Contrary to mammals, evolutionary rates of ectotherms are low, and for example within the Neogene only a few speciation events are recog- nisable (especially in amphibians - most Neogene species belong to extant species or species groups). The most important effects on the distribution and regional diversity of ectothermic vertebrates are migration and extinction events (Tihen, 1964; Böhme et al., 2001). Vertebrate migration events can generally be attributed to palaeogeographic (Rögl, 1999) and climatic events (Pickford and Morales, 1994). In the absence of physical barriers, climatic factors, such as temperature and humidity, may cause vertebrate migration (Van der Made, 1992). Several mammal (Van der Made, 1997; Rögl, 1999) and herpetofaunal (Böhme, 2001; Ivanov, 2001) migration events within and between the Old World continents of Africa, Asia and Europe have been detected within the Miocene. To investigate the influence of the Miocene global and regional climatic changes on migration and extinction events of ectothermic vertebrates, I have compared the temporal and spatial distribution of thermophilic and dry adapted ectotherms in Central Europe with data sets on Atlantic benthic foraminiferal oxygen isotope ratios.

\section{Materials and methods}

The studied record of Central European (palaeolatitude $42-45^{\circ} \mathrm{N}$, see Meulenkamp et al., 2000) Miocene ectothermic vertebrates comes from 230 outcrops (mostly the author's data, for complete occurrence matrix, see Appendix 1 in the online version of this paper) having ages ranging from 23 to $10 \mathrm{Ma}$ ago (chronostratigraphical and geochronological data after Reichenbacher et al., 1998; Steininger, 1999; Daxner-Höck, 2001). Intensive sampling during the last few decades yielded about 111 taxa of a herpetological fauna. Most of the localities (113; mainly sampled by Kurt Heissig, Munich) belong to the 'Older Series' and 'Middle Series' of the Bavarian part of the North Alpine Foreland Basin (NAFB, palaeolatitude $\left.42-43^{\circ} \mathrm{N}\right)$. Within the time interval $17-14.6$ Ma ago, eleven sedimentary cycles (OSM 0-10, Heissig, 1997; Böhme et al., 2001) and six mammal units (OSM A-F, Heissig, 1997) have been recognised. Therefore, a time resolution of less 
than $0.3 \mathrm{Ma}$ is available for most of these localities. The remaining outcrops represent fissure fillings located immediately north of the NAFB (karstic plateaus of the Swabian and Franconian Alb, $n=38$ ) and stratified outcrops in surrounding areas such as the Swiss and Austrian parts of the Molasse Basin, the North Bohemian Brown Coal Basin, the Lower Rhine Embayment, the Allier Basin, and the Vienna Basin. The age uncertainty of these localities based on the mammal biostratigraphy and magnetostratigraphy is $0.3-0.5 \mathrm{Ma}$ and only in some cases up to $1.0 \mathrm{Ma}$.

This large data set contains localities representing a wide range of environments (fissures, $n=48$; rivers, $n=112$; floodplains, $\mathrm{n}=31$; lakes, $n=22$; ponds, $n=11$; swamps, $n=4$; coastal marine environments, $n=2$; Böhme, 2000). The fossil material is disarticulated and is represented by isolated bones and teeth. In most cases their preservation is unweathered and unabraded. Assemblages from fluvial environments are found in channel-fill deposits and can be interpreted as generally autochthonous to their environment of deposition (Behrensmeyer, 1975, 1988). Especially the karstic and limno-fluvial environments (fissures, rivers, floodplains) are represented by a continous record through the investigated interval, which gives evidence that the data set is comparable in terms of depositional and taphonomic environment.

I extracted the number of thermophilic species of ectothermic vertebrates as a proxy for temperature. I classified an animal as thermophilic if its extant relatives live exclusively or mostly in tropical or subtropical climates. These groups are: the snakehead fishes (Channidae), the monitor lizards (Varanidae), the cordylid lizards (Cordylidae), the chameleons (Chamaeleonidae), the crocodiles (Tomistomidae, Alligatoridae), and the giant turtles (Geochelone s.1.). The geographical distribution of modern representatives of these groups is shown in Fig. 1. As a proxy for seasonality in precipitation, I extracted ectotherms which are mainly adapted to areas with a lower groundwater table and dryer environment. An animal is characteristic of these conditions if its abundance maxima are within the contemporary fissure fillings of the surrounding karst plateau (approxi- mately $50 \mathrm{~km}$ north) and occur with significantly lower frequencies and abundances in the limnofluvial molasse deposits. Such animals (here called 'dry adapted') are the albanerpetontid (Albanerpeton inexpectatum), the salamander (Salamandra sansaniensis), the green toad (Bufo cf. viridis), the big chameleon (Chamaeleo caroliquarti), the gekkos (Gekkonidae), the monitor lizards (Varanus hofmanni), and the sand boas (Bransateryx sp.).

\section{Results and analysis}

The temporal distribution of the selected thermophilic taxa in Central Europe is shown in Fig. 2. The First Occurrence Datum (FOD) for the snakehead fishes is early MN4 (Neogene Mammal units after Mein, 1975) in the fissure filling at Hermaringen 1. The beginning of the MN4 is dated at $18 \mathrm{Ma}$ (Steininger, 1999; Daxner-Höck, 2001). In the younger part of MN4 the Channidae are widespread in Western and Central Europe (e.g. La Romieu, France; Langenau, North Alpine Molasse Basin; Reichenbacher, 1993). The Last Occurrence Datum (LOD) of this group occurs between 13.2 and $12 \mathrm{Ma}$ at the early-middle MN8 (Laimering 1b, Kleineisenbach, both Bavarian Molasse Basin; Anwil, Swiss Molasse Basin).

Like the snakehead fishes, the monitor lizards (Varanus, Iberovaranus), have their FOD at the beginning of MN4 (Petersbuch 2 fissure filling, $18 \mathrm{Ma}$ ). Whereas Iberovaranus occurs in karst environments only, Varanus has a more extended distribution with a LOD in Central Europe in the Late Miocene fissure filling of Kohfidisch (MN10/11, around 8.7 Ma, Daxner-Höck, 2001).

The family Cordylidae is common in Eocene deposits and temporarily disappeared in Europe at the Eocene/Oligocene boundary (Auge, 1987). The next record is known from the terminal Oligocene locality Rott (Böhme and Lang, 1991) belonging to the Mammal Palaeogene unit MP30 (23.8-24.2 Ma, after Kempf et al., 1997). The FOD for the genus Palaeocordylus correlates to the earliest MN4 (fissure filling Petersbuch 2, 18 $\mathrm{Ma})$. The LOD of the Cordylidae occurs during the early MN5 (latest Karpatian) at Puttenhausen 


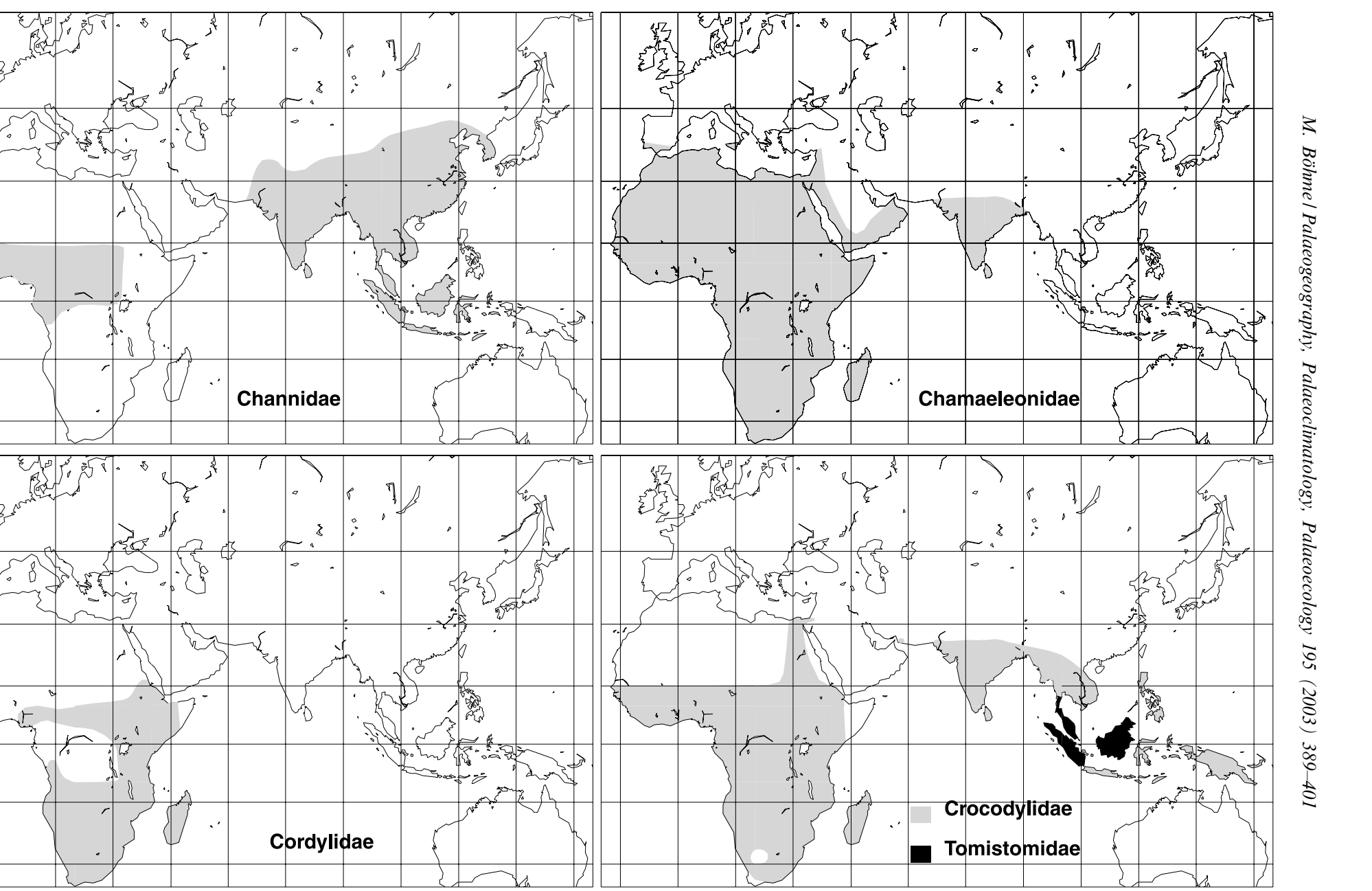

Fig. 1. Geographical distribution of selected extant thermophilic taxa (from Haller-Probst, 1997, and unpublished data) 


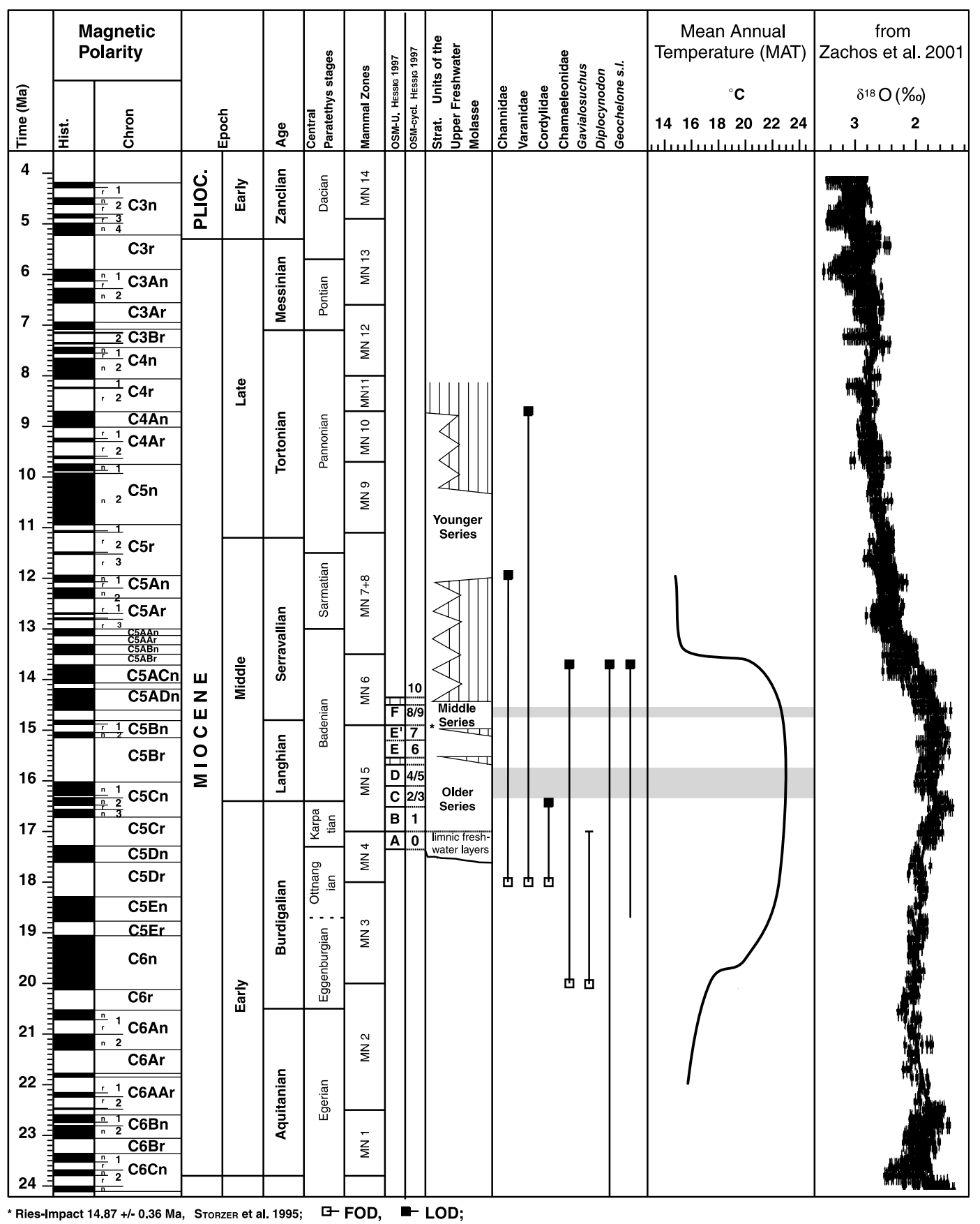

Fig. 2. Miocene time scale (after Berggren et al., 1995; Steininger, 1999; Daxner-Höck, 2001), litho- and biostratigraphical units of the Bavarian part of the Upper Freshwater Molasse of the NAFB (Böhme et al., 2001), distribution of thermophilic ectothermic vertebrates in Central Europe, the supposed evolution of the MAT (this paper, Fig. 5), and the global deep-sea oxygene isotope record (after Zachos et al., 2001). The shaded intervals indicate periods of higher seasonality in precipitation (this paper, Fig. 4). 
and Obergänserndorf (Böhme, 2002; 16.5-16.7 Ma, after Daxner-Höck, 2001). Thus, the cordylid lizards have a short temporal distribution in Central Europe, probably not exceeding 1.5 Ma.

The FOD of the family Chamaeleonidae correlates to early MN3 (20-19.5 Ma). Its oldest representatives are described from Merkur (Fejfar and Schleich, 1994) and Wintershof-West (Moody and Rocek, 1980). The last unambiguous chamaeleonids from the Molasse Basin are to be found at the Swiss locality Ornberg (Bolliger, 1992, end of MN6, 13.7 Ma after Kempf et al., 1997), so that the LOD of Chamaeleonidae in Central Europe is at about 13.7 Ma.

The taxonomic status and the phylogeny of the European giant turtle Geochelone sensu latu is still unclear (De Broin, 1977) and needs a revision. This large animal (more than $1 \mathrm{~m}$ carapax length) is definitively present in Central Europe from the late MN3 (locality Stubersheim 3, NAFB) to the end of MN6. The youngest record of Geochelone s.l. is from the Bavarian part of the NAFB (locality Kirrberg), with an approximate age of 13.514.0 Ma.

Two crocodiles, the genera Gavialosuchus (sensu Buffetaut et al., 1984, = Tomistoma of Antunes, 1994) and Diplocynodon occur in the Miocene of Central Europe. Gavialosuchus had its FOD in early MN3 at Eggenburg and its LOD in the Upper Marine Molasse of Southwest Germany (Bodensee area, locality of Bodman, Rossmann et al., 1999). The regression of the Upper Marine Molasse is diachronous (from east to west) and reached the East Switzerland/Bodensee area during late MN4 (Schlunegger et al., 1996; Kälin, 1997). Therefore, the minimum date for the LOD of Gavialosuchus is about $17 \mathrm{Ma}$. The regional extinction of Gavialosuchus can be correlated more likely with habitat shifting (regression of the Upper Marine Molasse - most of Gavialosuchus remains have been found in marine and littoral sediments, Buffetaut et al., 1984; Antunes, 1994) than with climatic deterioration.

The genus Diplocynodon is known from Europe since the Middle Eocene (Berg, 1966; Ginsburg and Bulot, 1997). The LOD in Central Europe is recorded in the locality Kirrberg (late MN6) from the Bavarian part of the NAFB. The LOD of Diplocynodon in Central Europe has been estimated at 13.5-14.0 Ma, i.e. contemporaneous with that of the chamaeleonids and giant turtles. Based on the big hamster Cricetodon cf. sansaniensis (Rummel and Kälin, 2003), the aforementioned localities (Ornberg, Kirrberg) are well dated.

In this context, a single crocodile tooth from the late Middle Miocene locality Anwil (Swiss Molasse Basin, early MN8, 13.2 Ma after Kälin and Kempf, 2002) is surprising. Since reworking can be excluded (B. Engesser, Basel, pers. commun., 2001), a somewhat longer occurrence in the southeastern part of the NAFB $\left(41.5^{\circ} \mathrm{N}\right.$ palaeolatitude) could be possible. In France, Diplocynodon disappears just as in Central Europe at the end of MN6 (LOD at the locality Sansan, Ginsburg and Bulot, 1997); on the Iberian Peninsula its record reaches to the lowermost Upper Miocene (Antunes, 1994; MN9, 9.7-11.1 Ma). In Southeast Europe (Bulgaria) Diplocynodon also reaches the Upper Miocene at different localities (open cast mines) of the West-Mariza Brown Coal Basin (von Huene and Nikolov, 1963, probably MN9). Thus, it is clear that the disappearance of the crocodile (Diplocynodon) shifted southward (Fig. 3) from Central Europe and France (palaeolatitude $38-45^{\circ} \mathrm{N}$, end of MN6, $13.5-14.0 \mathrm{Ma}$ ), to Southwest and Southeast Europe (palaeolatitude $30-37^{\circ} \mathrm{N}$, end of $\mathrm{MN} 9$, about $10 \mathrm{Ma}$ ).

Fig. 4 shows the distribution of dry adapted ectothermic vertebrates, as a proxy for seasonality in precipitation, within the Bavarian part of the NAFB. Two time spans (shaded areas on Figs. 2 and 4) display a frequent occurrence of five of the seven selected taxa. The first one is represented by sedimentary cycles 3-5 (OSM 3-5), characterised by the coexistence of Albanerpeton inexpectatum, Salamandra sansaniensis, Bufo cf. viridis, Chamaeleo caroliquarti, and Gekkonidae. The second one comprises cycle 9 (OSM 9) with Salamandra sansaniensis, Bufo cf. viridis, Chamaeleo caroliquarti, Varanus hofmanni and Bransateryx sp. The other sedimentary cycles yielded no records of dry adapted taxa (cycles 1, 2, 6) or only one taxon (cycles 7, upper part of 8, 10) or two taxa (cycle 0 ). This high frequency of dry adapted animals in the cycles $3-5$ (16.3 to $\sim 15.7 \mathrm{Ma}$, base of Early 


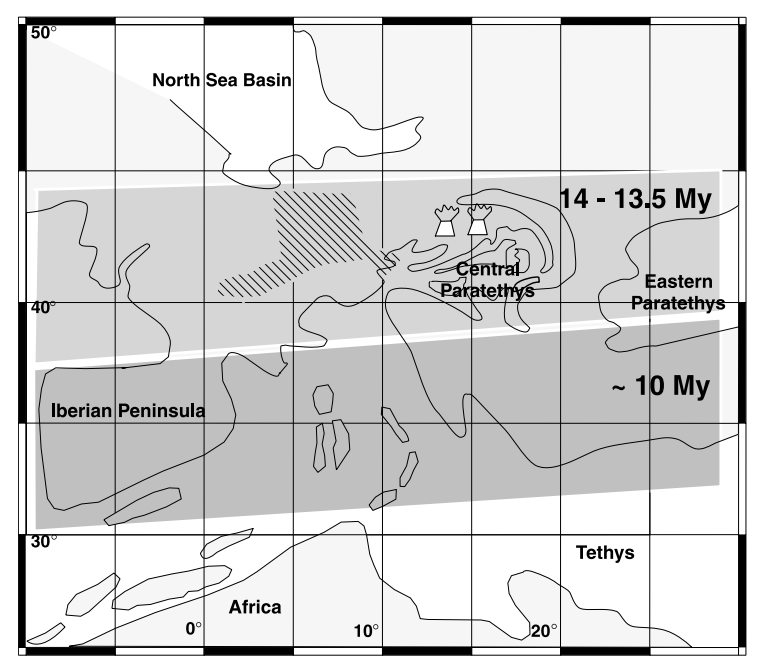

Fig. 3. Palaeogeographic map of the Middle Miocene of Europe (after Rögl, 1998) showing the subsequent regional extinction of Diplocynodon between palaeolatitudes 38 and $45^{\circ} \mathrm{N}$ at $14.0-13.5 \mathrm{Ma}$ (indicated by medium-grey colour) and between palaeolatitudes 30 and $37^{\circ} \mathrm{N}$ at about $10 \mathrm{Ma}$ (indicated by dark-grey colour; light-grey colour indicates the distribution of land masses; the working area is hatched; belts of stratovolcanoes are marked by pictograms).

Badenian) and cycle 9 (14.7 to $\sim 14.5 \mathrm{Ma}$, Early/ Middle Badenian transition) can be explained by an immigration from the northern karst plateau during periods with higher seasonality in precipitation, e.g. longer dry seasons.

\section{Discussion and conclusions}

The temporal distribution of selected thermophilic ectothermic vertebrates (Fig. 2) shows two subsequent migration events: chamaeleonids and Gavialosuchus at $20 \mathrm{Ma}$ and channids, varanids and cordylids at $18 \mathrm{Ma}$. These are followed by two regional extinction events: cordylids at 16.5-16.7 $\mathrm{Ma}$ and chamaeleonids, alligatorids and giant turtles at 14.0-13.5 Ma. Two immigrant groups, the Cordylidae (Auge, 1987) and the Chamaeleonidae (Raxworthy et al., 2002) are of African origin. The Chamaeleonidae entered Europe via an African-Eurasian landbridge (the so-called Gomphotherium landbridge), which was established since approximately $20 \mathrm{Ma}$, leading to important intercontinental faunal exchange (Van der
Made, 1997; Rögl, 1998; Agusti et al., 2001). The immigration of chamaeleonids was induced by both climatic (warming of the mid-latitudes) and palaeogeographic changes. In contrast, the cordylids appear later. The remaining immigrants $(G a-$ vialosuchus, channids, varanids) are of Asian origin. A European-Asian migration corridor, north of the Paratethys, was open since the Eocene/Oligocene boundary (Haq et al., 1987) and no physical barrier existed at that time. Therefore, these migration events within the Early Miocene can be explained by climatic change towards higher temperature, whereas the extinction of Gavialosuchus can be correlated with environmental change (regression of the Upper Marine Molasse - most of Gavialosuchus remains are to be found in marine and littoral sediments, Antunes, 1994). The regional extinction events of chamaeleonids, alligatorids and giant turtles can be explained by climatic deterioration. Less thermophilic herpetological groups (e.g. Lacertidae, Anguidae) are not affected by the thermal optimum and form an ever-present background (see Appendix 1 in the online version of this paper).

The dotted lines on Fig. 5 show the lower limits of the mean annual temperature (MAT), the minimal warm months temperature (mWMT), and the minimal cold months temperature (mCMT) during the investigated time span. The lines are constructed using the lowest temperatures derived from the extant distribution of the nearest living relatives of the investigated thermophilic taxa (see Table 1). Gavialosuchus is disregarded because of the relict distribution of its nearest living relative Tomistoma schlegeli (see Fig. 1). I consider the two migration events at $20 \mathrm{Ma}$ and $18 \mathrm{Ma}$ as indicative of a warming trend towards the Miocene Climatic Optimum. The time before the first migration event is characterised by a MAT not below $15.7^{\circ} \mathrm{C}$, a mCMT not below $-1.7^{\circ} \mathrm{C}$, and a mWMT not below $18.3^{\circ} \mathrm{C}$. Thereafter, the lower limit for MAT must have exceeded $17.4^{\circ} \mathrm{C}$ lasting from $20 \mathrm{Ma}$ to the time interval with the main extinction events between 14.0 and 13.5 Ma. During this warm episode the limit for the mWMT remained stable but the mCMT exceeded $8.0^{\circ} \mathrm{C}$. This coincides with the findings of wood and leaf remains with tropical affinities in the Ottnangian 


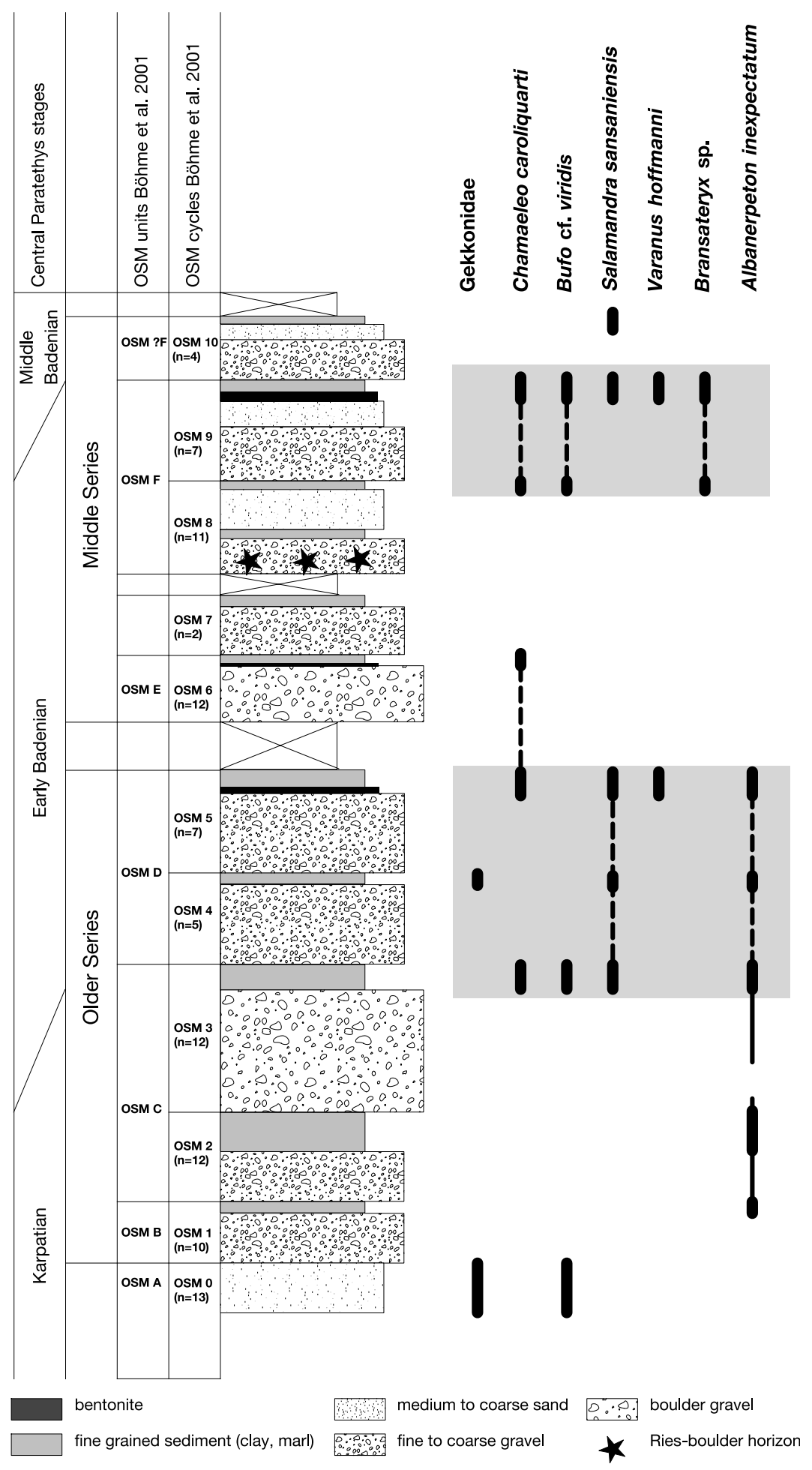


Table 1

Range of the MAT, the mWMT and the mCMT within the extant distribution of selected thermophilic taxa (after Haller-Probst, 1997).

\begin{tabular}{llll}
\hline & $\begin{array}{l}\mathrm{MAT}^{\circ} \mathrm{C} \\
\left({ }^{\circ} \mathrm{C}\right)\end{array}$ & $\begin{array}{l}\mathrm{mWMT} \\
\left({ }^{\circ} \mathrm{C}\right)\end{array}$ & $\begin{array}{l}\mathrm{mCMT}^{\circ} \mathrm{C} \\
\left({ }^{\circ} \mathrm{C}\right)\end{array}$ \\
\hline Chamaeleonidae & $17.4-28.8$ & $18.0-28.3$ & $8.0-22.2$ \\
Alligatoridae & $15.7-27.2$ & $18.3-26.1$ & $-1.7-25.0$ \\
Tomistoma schlegeli & $26.6-27.7$ & $22.2-23.3$ & $21.7-23.3$ \\
Varanidae & $14.8-28.1$ & $13.9-26.1$ & $-3.9-19.4$ \\
Cordylidae & $17.0-30.1$ & $15.0-31.0$ & $3.0-23.0$ \\
Geochelone ssp. & $17.0-28.7$ & $15.0-26.1$ & $3.0-22.2$ \\
\hline
\end{tabular}

and Karpatian from South Germany and in the Badenian from Romania (Heliconiaceae, Bombacaceae, Euphorbiaceae, Ebenaceae, Flacourtiaceae, Dipterocarpaceae, Meliaceae, Tiliaceae, Arecaceae; see Selmeier, 1999; Schweigert, 1992, 1998; Iamandei and Iamandei, 2000). These palaeobotanical proxies indicate a paratropical rainforest with a MAT of $20^{\circ} \mathrm{C}$ or higher (Schweigert, 1992). The occurrence of bauxites and laterites in the Vogelsberg volcanic area (Schwarz, 1997) provides additional information. The estimated ages for the volcanic rocks vary between 16.2 and 15.5 Ma. Proxy models according to Price et al. (1997) indicate that modern bauxite formation requires a MAT higher than $22^{\circ} \mathrm{C}$, six or less dry months (less than $60 \mathrm{~mm}$ rainfall) and a rainy season resulting in an annual mean precipitation of more than $1200 \mathrm{~mm}$. This corresponds excellently with the distributon maxima of dry adapted ectotherms (Fig. 4), indicating an increasing seasonality of precipitation in the Badenian between 16.3 and $\sim 15.7 \mathrm{Ma}$ (base of Early Badenian) and between 14.7 and $\sim 14.5 \mathrm{Ma}$ (Early/Middle Badenian transition).

These periods with high seasonality antedate two main hiatuses within the Upper Freshwater Molasse section, between the sedimentary cycles OSM 5 and 6 and above cycle OSM 10 (Fig. 4). Both hiatuses can be attributed to minor tectonic movements of the NAFB (Reichenbacher et al., 1998). But during the Early Badenian no significant uplift in the Eastern Alps has been documented (Kuhlemann and Kempf, 2002). Thus a direct correlation between periods of higher seasonality in precipitation and Alpine uplift is rather unlikely.

A better explanation for the increased seasonality at the beginning of the Badenian can be inferred from the reorganisation of the Central Paratethys realm. The subduction of the North European platform under the Carpathian-Pannonian block and a back-arc extension associated with diapiric uprise of the asthenospheric mantle led to extensive explosive-effusive volcanism (Vass et al., 1988; Kováč et al., 2000) and to the tectonically-controlled sea-level changes in the Paratethys (Hudáčková et al., 2000). Especially during the Early Badenian, andesitic and rhyodacitic-rhyolitic volcanism culminated in the West Carpathian and Slovakian Basins (Vass et al., 1988) and gave rise to a belt of stratovolcanoes up to $4000 \mathrm{~m}$ or even higher palaeoaltitude (J. Lexa, Bratislava, pers. commun., 2001). This belt immediately east of Central Europe at palaeolatitude $43-44^{\circ} \mathrm{N}$ most probably influenced the regional atmospheric circulation, especially if the dominant wind direction was from the east as proposed by Utescher and Bruch (2000, fig. 9).

Fig. 4. Composite section of the Older and Middle Series of the Upper Freshwater Molasse (Bavarian part of the NAFB; thickness about $150 \mathrm{~m}$ ) and the distribution of dry adapted ectothermic vertebrates ( $n$ refers to the number of studied localities from each cycle). See Appendix 1 in the online version of this paper for locality data. The age of the Ries-boulder horizon (marked by asterix) is $14.87 \pm 0.36 \mathrm{Ma}$ (Storzer et al., 1995), the age of the bentonite of OSM cycle 9 is $14.6 \pm 0.8$ Ma (Storzer and Gentner, 1970). The shaded areas indicate periods of higher seasonality in precipitation. 
This interpretation implies that moist air masses originating in the Eastern Paratethys probably had no major influence on Central European climate. Coevally, this effect could have interfered with sea-level falls in the West Carpathian-North Pannonian Basins at the Karpatian/Badenian and the Lower Badenian/Middle Badenian boundaries (Hudáčková et al., 2000) which supposedly resulted in a decrease of moist air mass production.

Combining herpetological, palaeobotanical and bauxite formation data, it can be concluded that the Miocene Climatic Optimum in Central Europe ranged from about 18 to $14.0-13.5 \mathrm{Ma}$ (Ottnangian to Early/Middle Badenian) and was characterised by a high MAT exceeding $17.4^{\circ} \mathrm{C}$ to at least $20-22^{\circ} \mathrm{C}$ (dashed line in Fig. 5). A period of high precipitation during the Ottnangian and Karpatian was followed by a period with stronger seasonality in precipitation (up to six dry months) in the Lower Badenian.

During the interval from 14.0 to $13.5 \mathrm{Ma}$, a rapid climatic deterioration occurred. This cooling event, which led to the contemporary regional (Central European) extinction of alligators, chameleons and giant turtles, is characterised by a decrease of the mCMT of more than $11^{\circ} \mathrm{C}$ and the possible occurrence of frost periods (Fig. 5). The MAT probably dropped at least $7^{\circ} \mathrm{C}$ to levels between $15.4^{\circ} \mathrm{C}$ and $14.8^{\circ} \mathrm{C}$. This climatic deterioration resulted in a stronger temperature gradient in Europe and marks the beginning of a more distinct climatic zonation on the continent. The thermophilic ectotherms survived only in southern regions (south of $37^{\circ} \mathrm{N}$ palaeolatitude) as is shown for the crocodile Diplocynodon (Fig. $3)$. The record of ectothermic vertebrates suggests that the winter temperatures formed the major driving factor in the Miocene thermal evolution of the mid-latitudes, thereby confirming palaeobotanical results from both Europe (Utescher and Bruch, 2000, p. 147) and North America (Wolfe, 1994, p. 201). Additionally, the palaeobotanical investigations in the mid-latitudes of western North America (Wolfe, 1994) show the same trends (increasing MAT between 20 and $18 \mathrm{Ma}$, decreasing MAT around $13 \mathrm{Ma}$ ). The significantly lower values of MAT $\left(15.4-16.6^{\circ} \mathrm{C}\right)$ are probably caused by higher palaeoaltitudes in this region.

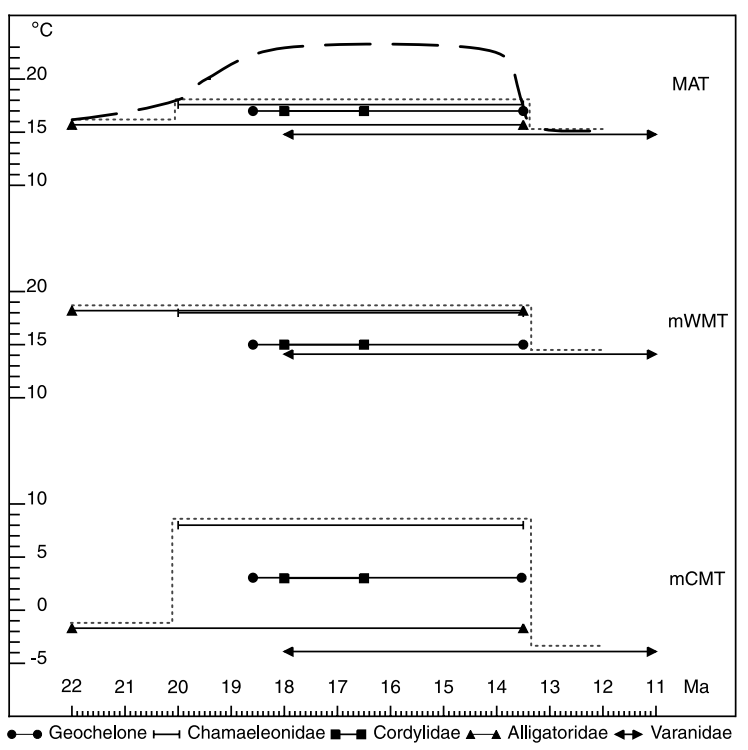

Fig. 5. Lower limits (dotted line) of the MAT, the mWMT and the mCMT as inferred from the distribution of thermophilic ectothermic vertebrates, and the supposed evolution of the MAT (dashed line) based on palaeobotanical and bauxite occurrence data within the Lower and Middle Miocene of Central Europe $\left(42-45^{\circ} \mathrm{N}\right.$ palaeolatitude; data sets, see Appendix 1 in the online version of this paper).

The results show further good agreement with the record of global deep-sea oxygen isotope ratios (Fig. 2). This record indicates an earliest Miocene cooling event (Mi-1 glaciation at 23.0 Ma), followed by a warming peaking $17-15 \mathrm{Ma}$ in the Mid-Miocene Climatic Optimum. Renewed cooling and reestablishment of the major ice-sheets on Antarctica led to a decline of the deep-sea temperature between 14 and $15 \mathrm{Ma}$ (Zachos et al., 2001, fig. 2). The investigation presented here shows that at least in continental deposits of the midlatitudes of Europe this cooling event can be dated somewhat later, between 14.0 and 13.5 Ma.

\section{Acknowledgements}

I want to express my gratitude to August Ilg (Düsseldorf) for important assistance during the preparation of this paper. I would like to thank Susan E. Evans (London), Jan van Dam (Utrecht) and Finn Surlyk (Copenhagen) for critically reviewing the manuscript and very helpful com- 
ments, Alexander Altenbach (Munich), Gudrun Daxner-Hoeck (Vienna), Burkhart Engesser (Basel), Michael Rummel (Augsburg), Marguerite Hugueney (Lyon), Jaroslav Lexa (Bratislava), and especially Kurt Heissig (Munich) for many helpful discussions and access to the collections studied, as well as Robert Lundin (Arizona) and Christoph Dietrich (Düsseldorf) for improving the English text of the manuscript. Research funding was provided by the Deutsche Forschungsgemeinschaft which awarded a postdoctoral fellowship to the author (BO 1550/3).

\section{References}

Agusti, J., Cabrera, L., Garces, M., Krijgsman, W., Oms, O., Peres, J.M., 2001. A calibrated mammal scale for the Neogene of Western Europe. State of the art. Earth-Sci. Rev. 52, 247-260.

Alroy, J., Koch, P.L., Zachos, J.C., 2000. Global climate change and North American mammalian evolution. In: Erwin, D.H., Wing, S.L. (Eds.), Deep Time - Paleobiology's Perspective. Paleobiology, Suppl. to vol. 26 (4), pp. 103-147.

Antunes, M.T., 1994. On Western Europe Miocene gavials (Crocodylia) their palaeogeography, migrations and climatic significance. Comun. Inst. Geol. E Mineiro 80, 57-69.

Auge, M., 1987. Les Cordylidae (Reptila, Lacertilia) de l'Éocène français. Bull. Mus. Nat., Paris 4e ser., 9, Section C, 2, 181-196.

Behrensmeyer, A.K., 1975. The taphonomy and paleoecology of Plio-Pleistocene vertebrate assemblages east of Lake Rudolf, Kenya. Bull. Mus. Comp. Zool. 146, 473-578.

Behrensmeyer, A.K., 1988. Vertebrate preservation in fluvial channels. Palaeogeogr. Paleoclimatol. Palaeoecol. 63, 183199.

Berg, D.E., 1966. Die Krokodile insbesondere Asiatosuchus und aff. Sebecus? aus dem Eocän von Messel bei Darmstadt/Hessen. Abh. hess. L.-Amt Bodenf. 52, 1-105.

Berggren, W.A., Kent, D.V., Swisher, C.C., Aubry, M.P., 1995. A revised Cenozoic geochronology and chronostratigraphy. In: Berggren, W.A., Kent, D.V., Aubry, M.P., Hardenpol, J. (Eds.), Geochronology, Time Scales and Global Stratigraphic Correlation. SEPM Spec. Publ. 54, Tulsa, pp. 129-212.

Böhme, M., 2000. Characterization of limno-fluvial ecosystems based on lower vertebrates (Lower/Middle Miocene, Southern Germany). J. Vertebr. Paleontol. 20, 30A.

Böhme, M., 2001. The oldest representative of a brown frog (Salientia, Ranidae) from the Lower Miocene of Germany and the ecology of this group during the Neogene. Acta Palaeontol. Polonica 46, 119-124.

Böhme, M., 2002. Lower Vertebrates (Teleostei, Amphibia, Sauria) from the Karpatian of the Korneuburg Basin - pa- laeoecological, environmental and palaeoclimatological implications. Beitr. Paläontol. 27, 339-353.

Böhme, M., Gregor, H.J., Heissig, K., 2001. The Ries- and Steinheim meteorite impacts and their effect on environmental conditions in time and space. In: Buffetaut, E., Koeberl, C. (Eds.), Geological and Biological Effects of Impact Events, Springer, Berlin, pp. 217-235.

Böhme, W., Lang, M., 1991. The reptilian fauna of the Late Oligocene locality Rott near Bonn (Germany) with special reference to the taxonomic assignment of 'Lacerta' rottensis von Meyer, 1856. N. Jb. Geol. Paläontol., Mh. 1991 (9), $515-525$.

Bolliger, T., 1992. Kleinsäugerstratigraphie der miozänen Hörnlischüttung (Ostschweiz). Dokumenta naturae 75, 1297.

Buffetaut, E., Crouzel, F., Juillard, F., Stigliani, F., 1984. Le crocodilien longirostre Gavialosuchus dans le Miocène moyen de Polastron (Gers, France). Geobios 17, 113-117.

Daxner-Höck, G., 2001. Early and Late Miocene Correlation (Central Paratethys). Ber. Inst. Geol. Paläontol. Karl-Franzens-Univ. Graz 4, 28-33.

De Broin, F., 1977. Contribution à l'étude des Chéloniens Chéloniens continentaux du Crétacé et du tertiaire de France. Mém. Mus. Natl. Hist. Nat., nouv. ser., C 38, 1340.

Fejfar, O., Schleich, H.H., 1994. Ein Chamaeleonfund aus dem Orleanium des Braunkohle-Tagebaus Merkur-Nord (Nordböhmen). Cour. Forsch.inst. Senckenberg 173, 167-173.

Flower, B.P., Kennett, J.P., 1994. The Middle Miocene climatic transition: East Antarctic ice sheet development, deep ocean circulation and global carbon cycling. Palaeogeogr. Palaeoclimatol. Palaeoecol. 108, 537-555.

Ginsburg, L., Bulot, C., 1997. Les Diplocynodon (Reptilia, Crocodylia) de l'Orléanien (Miocène inférieur à moyen) de France. N. Jahrb. Geol. Paläontol., Mon.heft. 1999 (6), 321330.

Haller-Probst, M., 1997. Die Verbreitung der Reptilia in den Klimazonen der Erde. Cour. Forsch.instit. Senckenberg 203, $1-67$.

Haq, B., Hardenbol, J., Vail, P., 1987. The chronology of fluctuating sea levels since the Triassic. Science 235, 11561166.

Heissig, K., 1997. Mammal faunas intermediate between the reference faunas of MN4 and MN6 from the Upper Freshwater Molasse of Bavaria. In: Aguilar, J.P., Legendre, S., Michaux, J. (Eds.), Actes du Congrès BiochroM'97. Mem. Trav. E.P.H.E., Inst. Montpellier 21, pp. 537-546.

Hudáčková, N., Holcová, K., Zlinská, A., Kováč, M., Nagymarosy, A., 2000. Peleoecology and eustasy: Miocene 3rd order cycles of relative sea-leval changes in the Western Carpathian. North Slovak Geol. Mag. 6, 95-100.

Iamandei, S., Iamandei, E., 2000. Middle Miocene lignoflora in the Southern Apuseni (Romania), and its paleogeographical significance. Slovak Geol. Mag. 6, 306-307.

Kälin, D., 1997. A mammal zonation of the Upper Marine Molasse of Switzerland reconsidered. A local biozonation of MN2-MN5. New magnetostratigraphic calibration of 
Early to Middle Miocene mammal biozones of the North Alpine Foreland Basin. In: Aguilar, J.P., Legendre, S., Michaux, J. (Eds.), Actes du Congres BiochroM'97. Mem. Trav. E.P.H.E., Inst. Montpellier 21, pp. 515-536.

Kälin, D., Kempf, O., 2002. High-resolution mammal biostratigraphy in the Middle Miocene continental record of Switzerland (Upper Freshwater Molasse, MN4-MN9, 17-10 Ma). 16. Internationale Senckenberg Konferenz des Forschungsinstitutes und Naturmuseum Senckenberg, 'The Middle Miocene crisis', EEDEN-meeting, 14-16 November, Frankfurt am Main, 67.

Kempf, O., Bolliger, T., Kälin, D., Engesser, B., Matter, A., 1997. New magnetostratigraphic calibration of Early to Middle Miocene mammal biozones of the North Alpine Foreland Basin. In: Aguilar, J.P., Legendre, S., Michaux, J. (Eds.), Actes du Congres BiochroM'97. Mem. Trav. E.P.H.E., Inst. Montpellier 21, pp. 547-561.

Kováč, M., Márton, E., Šefera, J., Koneæny, V., Lexa, J., 2000. Miocene development of the Carpathian chain and the Pannonian Basin: Movement trajectory of lithospheric fragments, subduction and diapiric uprise of asthenospheric mantle. Slovak Geol. Mag. 6, 77-84.

Kuhlemann, A., Kempf, O., 2002. Post-Eocene evolution of the North Alpine Foreland Basin and its response to Alpine tectonics. Sediment. Geol. (in press).

Ivanov, M., 2001. Changes in the composition of the European snake fauna during the Early Miocene and the Early/Middle Miocene transition. Paläontol. Z. 74, 563-575.

Markwick, P.J., 1998. Fossil crocodilians as indicators of Late Cretaceous and Cenozoic climates: implications for using palaeontological data in reconstructing palaeoclimate. $\mathrm{Pa}-$ laeogeogr. Palaeoclimatol. Palaeoecol. 137, 205-271.

Mein, P., 1975. Resultats du groupe de travail des vertebres: biozonation du Neogene mediterranéen partir des mammifères. In: Senes, J. (Ed.), Report on Activity of the RCMNS Working Groups (1971-1975), Bratislava, pp. 78-81.

Meulenkamp, J., et al. (23 co-autors), 2000. Early Langhian. In: Dercourt J., Gaetani, M., et al. (Eds.), Atlas Peri-Tethys, Palaeogeographical maps. CCGM/CGMW, Paris, map 21.

Moody, S., Rocek, Z., 1980. Chamaeleo caroliquarti (Chamaeleonidae, Sauria): a new species from the Lower Miocene of Central Europe. Vestnik Ustredniho ustavu geol. 55, 85-92.

Ostrom, J.H., 1970. Terrestrial vertebrates as indicators of Mesozoic climate. Proc. North Am. Paleontol. Conv. 1, 347376.

Pickford, M., Morales, J., 1994. Biostratigraphy and palaeobiogeography of East Africa and the Iberian peninsula. Palaeogeogr. Paleoclimatol. Palaeoecol. 112, 297-322.

Price, G.D., Valdes, P.J., Shellwood, B.W., 1997. Prediction of modern bauxite occurence: implications for the climate reconstruction. Palaeogeogr. Paleoclimatol. Palaeoecol. 131, $1-14$.

Raxworthy, C.J., Forstner, M.R.J., Nussbaum, R.A., 2002. Chamaeleon radiation by oceanic dispersal. Nature 415, 784-787.

Reichenbacher, B., Böttcher, R., Bracher, H., Doppler, G., von Engelhardt, W., Gregor, H.-J., Heissig, K., Heizmann,
E.P.J., Hofmann, F., Kälin, D., Lemcke, K., Luterbacher, H., Martini, E., Pfeil, F., Reiff, W., Schreiner, A., Steininger, F.F., 1998. Graupensandrinne - Ries-Impakt: Zur Stratigraphie der Grimmelfinger Schichten, Kirchberger Schichten und Oberen Süßwassermolasse. Z. dtsch. geol. Ges. 149, 127-161.

Reichenbacher, B., 1993. Mikrofaunen, Paläogeographie und Biostratigraphie der miozänen Brack- und Süßwassermolasse in der westlichen Paratethys unter besonderer Berücksichtigung der Fisch-Otolithen. Senck. Lethaea 73, 277-374.

Rögl, F., 1998. Palaeogeographic considerations for Mediterranean and Paratethys seaways (Oligocene to Miocene). Ann. Naturhist. Mus. Wien 99A, 279-311.

Rögl, F., 1999. Circum mediterranean Miocene Paleogeography. In: Rössner, G.E., Heissig, K., (Eds.), The Miocene Land Mammals of Europe. Verlag Dr. Friedrich Pfeil, München, pp. 9-24.

Rossmann, T., Berg, D.E., Salisbury, S., 1999. Studies on Cenozoic crocodiles: 3. Gavialosuchus cf. gaudensis (Eusuchia: Tomistomidae) from the Lower Miocene of Germany. N. Jb. Geol. Paläont. Mh. 1999 (6), 321-330.

Rummel, M., Kälin, D., 2003. Die Gattung Cricetodon (Mammalia, Rodentia) aus dem Mittelmiozän der Schweizer Molasse. Eclogae geol. Helvetiae (in press).

Schlunegger, F., Burbank, D.W., Matter, A., Engesser, B., Mödden, C., 1996. Magnetostratigraphic calibration of the Oligocene to Middle Miocene (30-15 Ma) mammal biozones and depositional sequences of the Swiss Molasse Basin. Eclogae geol. Helvetiae 89, 753-788.

Schwarz, T., 1997. Lateritic bauxite in central Germany and implications for Miocene palaeoclimate. Palaeogeogr. Paleoclimatol. Palaeoecol. 129, 37-50.

Schweigert, G., 1992. Die untermiozäne Flora (Karpatium, MN5) des Süßwasserkalkes von Engelswies bei Meßkirch (Baden-Württemberg). Stuttg. Beitr. Naturk. B 188, 1-55.

Schweigert, G., 1998. Das Randecker Maar. Stuttg. Beitr. Naturk. C 43, 1-70.

Selmeier, A., 1999. Kieselhölzer (Bombax, Carapa, Cinnamomum) aus dem untermiozänen Ortenburger Schotter, Ostmolasse Bayern. Mitt. Bayer. Staatsslg. Paläontol. Hist. Geol. 39, 219-236.

Steininger, F.F., 1999. Chronostratigraphy, Geochronology and Biochronology of the Miocene 'European Land Mammal Mega-Zones' (ELMMZ) and the Miocene 'MammalZones (MN-Zones)'. In: Rössner, G.E., Heissig, K. (Eds.): The Miocene Land Mammals of Europe. Verlag Dr. Friedrich Pfeil, München, pp. 9-24.

Storzer, D., Gentner, W., 1970. Spaltspuren-Alter von Riesgläsern, Moldaviten und Bentoniten. Jahresber. Mitt. Oberrheinischen geol. Ver. N.F. 52, 97-111.

Storzer, D., Jessberger, E.K., Kunz, J., Lange, J.M., 1995. Synopsis von Spaltspuren- und Kalium-Argon-Datierungen an Ries-Impaktgläsern und Moldaviten. Exkursionsführer $u$. Veröfftl. GGW 195, 79-80.

Tihen, J.A., 1964. Tertiary changes in the herpetofaunas of the temperate North America. Senckenbergiana biol. 45, 265 279. 
Utescher, T., Bruch, A., 2000. Klimaentwicklung vom Oligozän - Pliozän. In: Hemleben et al. (Eds.), Klima- und Ökosystementwicklung im Oligozän/Miozän des Ostalpenraumes. Bericht (1998-2000) des Sonderforschungsbereiches 275 'Klimagekoppelte Prozesse in meso- und känozoischen Geoökosystemen', Universität Tübingen 1, pp. 141-176.

Van der Made, J., 1992. Migrations and Climate. Cour. Forsch.inst. Senckenberg 153, 27-37.

Van der Made, J., 1997. Intercontinental dispersal events, eustatic sea level and Early and Middle Miocene stratigraphy. In: Aguilar, J.P., Legendre, S., Michaux, J. (Eds.), Actes du Congres BiochroM'97. Mem. Trav. E.P.H.E., Inst. Montpellier 21, pp. 75-81.

Vass, D., Kováč, M., Konečný, V., Lexa, J., 1988. Molasse basins and volcanic activity in West-Carpathian Neogene its evolution and geodynamic character. Geol. Zbornik Geol. Carpathica 39, 539-561.

von Huene, F., Nikolov, I., 1963. Ein pliozänes Krokodil in Bulgarien. N. Jahrb. Geol. Paläontol. Abh. 118, 266-271.

Walter, H., Breckle, S.W., 1983. Ökologie der Erde, 1. Ökologische Grundlagen in globaler Sicht. Gustav Fischer, Stuttgart.

Wolfe, J.A., 1994. Tertiary climate changes at middle latitudes of western North America. Palaeogeogr. Paleoclimatol. Palaeoecol. 108, 195-205.

Zachos, J., Pagani, M., Sloan, L., Thomas, E., Billups, K., 2001. Trends, rhythms, and aberrations in global climate $65 \mathrm{Ma}$ to present. Science 292, 686-693. 